OnLine Journal of Biological Sciences 10 (2): 92-102, 2010

ISSN 1608-4217

(C) 2010 Science Publications

\title{
Density and Population Estimation of the Bornean Elephants (Elephas maximus borneensis) in Sabah
}

\author{
${ }^{1}$ Raymond Alfred, ${ }^{2}$ Abd Hamid Ahmad, ${ }^{1}$ John Payne, ${ }^{3}$ Christy William and ${ }^{4}$ Laurentius Ambu \\ ${ }^{1}$ Borneo Species Programme, WWF-Malaysia, 1-6-W11, 6th Floor, CPS Tower, \\ Centre Point Complex, Jalan Centre Point, 80000 Kota Kinabalu, Sabah, Malaysia \\ ${ }^{2}$ University Malaysia Sabah, Locked Bag 2073, 88999 Kota Kinabalu, Sabah, Malaysia \\ ${ }^{3}$ WWF Asian Rhinoceros and Elephant Action Strategy, WWF-International, Gland, Switzerland \\ ${ }^{4}$ Department of Sabah Wildlife, 5th Floor, Block B, Wisma Muis, 88100 Kota Kinabalu, Sabah, Malaysia
}

\begin{abstract}
Problem statement: In Asia, four elephant subspecies have been identified, Elephas maximus maximus from Sri Lanka, Elephas maximus summatranus from Sumatra, Elephas maximus borneensis (based on recent DNA analysis) from Borneo and Elephas maximus indicus, from mainland Asia. The Bornean elephant has a limited distribution and is found only in the northeastern part of the island, (Malaysian Sabah and Indonesian Kalimantan). Previous estimations for the population in Sabah have ranged between 500-2000 elephants. These estimations have been carried out through a non-systematic approach, either via interview or from direct sightings or extrapolating population count data from limited sites. In order to prepare the conservation plan for this species in Sabah, there is a need to establish reliable information on their density and population size. The main objective of this study was to determine the elephant density and population size in five main elephant managed ranges in Sabah. Approach: In this study, relative distribution and spatial density of the Bornean elephant was developed and established, using a systematic line transect survey and a long term monitoring of dung decay rates. We conducted the elephant population census in Sabah between July 2007 and December 2008. Using a line-transect dung-count methodology, we surveyed 216 line transects; with a total distance of $186.12 \mathrm{~km}$, in five main elephant managed ranges. Namely (i) Tabin Wildlife Reserve, (ii) Lower Kinabatangan, (iii) Central Forest, (iv) North Kinabatangan and (v) Ulu Kalumpang. Results: We presented the elephant density estimate using long term monitoring of dung decay rates. In each range, the elephant's density varied depending on the size of the suitable habitat. The size of the suitable habitat was derived from WWF's study report (WWF-Malaysia, 2008). Densities were analyzed following line-transect analysis guidelines and were computed using the software Distance v6.0. Conclusion: Our survey indicated that approximately 2,040 (95\% CI: 1,1843,652 ) elephants remain in the five main ranges in Sabah, with the largest population being in the unprotected central forests. Elephant density was highest in ranges where habitat has been removed and elephants are concentrated in remaining forest areas. These results provide new baseline data for the elephant population in Sabah.
\end{abstract}

Key words: Density, dung counts, dung decay, elephant population size, Sabah

\section{INTRODUCTION}

Conservation and management of endangered species in the wild requires adequate knowledge of their distribution and population size (Sukumar, 1989).

Currently, the Bornean elephant is one of four subspecies present in Asia: (1) Elephas maximus indicus in mainland Asia; (2) Elephas maximus maximus in Sri Lanka; (3) Elephas maximus sumatrensis in Sumatra,
Indonesia and (4) Elephas maximus borneensis in Malaysian and Indonesian Borneo (Buckland et al., 2001).

The origin of the Bornean elephant is still very controversial, despite the publication of a genetic study by Fernando et al. (2003) indicating the distinctiveness of the Bornean elephant and its derivation from Sundaic stock. Fernando et al. (2003) recognizes the Bornean elephant as a separate evolutionary significant unit and claims that independent evolution has occurred for some 300,000 years since Pleistocene colonization.

Corresponding Author: Raymond Alfred, Borneo Species Programme, WWF-Malaysia, 1-6-W11, 6th Floor, CPS Tower, Centre Point Complex, Jalan Centre Point, 80000 Kota Kinabalu, Sabah, Malaysia 
However, the presence of this taxon in Borneo for more than 300,000 years is questionable. There has been no authentication or confirmed finds of Asian elephant in any excavation, including in Niah cave (Sarawak) and in Madai cave (Sabah, within the species' present range) although other large ungulates (Rhinocerus sondaicus, Dicerorhinus sumatrensis and Tapirus indicus) were represented. Another theory is that the elephants are descended from imported domestic elephants that originate from Java and were released in northeast Borneo (Cranbrook et al., 2008). Therefore, Borneo could be the refuge of the Javan elephant and Elephas maximus borneensis the descendant of E. m. sondaicus. DNA analysis of ancient bones from Sulu elephants and/or from Javan elephants and comparison with DNA from the Bornean elephants could assist in determining the origin of the Bornean elephant.

In 1992, the estimated population size for the elephants in Sabah ranged from 500-2,000 (Andau et al., 1992). These estimations were based on survey work conducted in three forest areas only, namely (i) Tabin Wildlife Reserve, (ii) Lower Kinabatangan and (iii) Deramakot Forest Reserve (Forest Management Unit 19) and then extrapolated to cover the central forest of Sabah. The second effort to provide elephant population numbers was during the preparation of the Elephant Action Plan for Sabah in 2002. The elephant density was estimated using survey data gathered by Boonratana (1997), but as the size of the suitable habitat was not determined, the figures are likely to be an approximation. The elephant population estimation for Sabah is likely to be inaccurate due to (i) the lack of a systematic approach across all key habitat areas and (ii) elephant populations were estimated in certain areas only and then extrapolated to cover the central forest of Sabah.

Dung counts are the most common type of indirect census method for counting elephants in the wild. Since the early 1980s, as interest quickened in the status of elephants in the forests of west and central Africa, more and more dung counts have been conducted. In the late 1980s researchers in India and then in south-east Asia turned to dung counts for estimating the numbers of Asian elephants, Elephant maximus. The proliferation of forest elephant surveys on both continents has stimulated the rapid evolution of dung survey techniques. These methods have been described previously by Barnes and Jensen (1987) and Dawson and Dekker (1992). Line transect techniques have been further improved by Burnham et al. (1980) and Meredith, (2008).

To determine the elephant population numbers and density in different forest habitat, detailed line transect surveys were conducted in this study. The size of suitable habitat for a population was determined through a key habitat suitability assessment, using the data derived from a state-wide survey on the presence and absence of Bornean elephant in all key habitats in Sabah (WWF-Malaysia, 2008).

This study is the first effort in determining the elephant density and population size in Sabah using a systematic line transect survey method and long term monitoring of dung decay rates.

\section{MATERIALS AND METHODS}

Our survey was conducted in five main elephant managed ranges $\left(4^{\circ} 30^{\prime} \mathrm{N}-5^{\circ} 45 \mathrm{~N}, 117^{\circ} 00^{\prime} \mathrm{E}-119^{\circ} 00^{\prime} \mathrm{E}\right)$, namely:

- Tabin Range

- Lower Kinabatangan Range

- Central forest Range (Ulu Segama, Danum Valley, Malua, Kuamut, Gunung Rara and Kalabakan)

- North Kinabatangan Range (Deramakot, Tangkulap and Segaliud Forest Reserve)

- Ulu Kalumpang Range

Three of the ranges, Tabin Range (Wildlife Reserve), Lower Kinabatangan Range (Wildlife Sanctuary) and Ulu Kalumpang Range (Protected Forest), are protected forest. It should be noted that the protected forest of the Lower Kinabatangan Range is fragmented into ten blocks along the Kinabatangan River. The other two ranges are commercial forest for timber production.

Figure 1 shows the location of the five main elephant managed ranges, where field surveys were carried out.

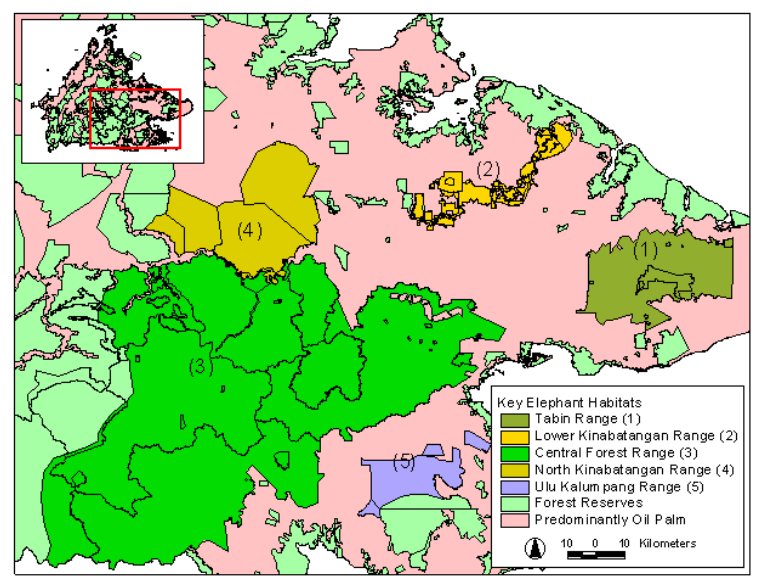

Fig. 1: Location of elephant managed ranges, where field survey was carried out 
Line transect survey: Dung counts are the most common type of indirect census method for counting elephants. The dung count method requires a translation of the data into the number of elephants. To estimate elephant numbers and density, the following data was acquired:

- Estimation of the number of dung-piles, or the density of dung-piles per $\mathrm{km}^{2}$

- Estimation of the defecation rate of elephants

- Estimation of the mean rate of dung decay

- Combination of the three estimates above to give an estimate of elephant numbers and density of elephant per $\mathrm{km}^{2}$ or per ha

Estimation of the number of dung-piles per $\mathbf{k m}^{2}$ : The line transect sampling technique developed by Burnham et al. (1980) and Meredith (2008) was used to estimate dung density. Line transects were systematically placed $3 \mathrm{~km}$ apart along a predetermined compass bearing, oriented perpendicular to roads, major trails, rivers or streams in forested areas. Transects were placed on both sides of the roads, trails and rivers. The starting point of the first transect was selected at random. Topographic features like rivers and roads were selected as they allowed accessibility and adequate coverage of a large census area within a limited time-frame. This could however bias the data due to the behavior of the elephants, since in certain forest areas the elephants are likely to use the logging roads for access trails. Use of logging roads by elephants has been frequently observed during field work. The effect on the data accuracy will be discussed further.

Transects were walked only once and data was collected while simultaneously preparing the transects. Information gathered was recorded onto standard data recording sheets. Perpendicular distances were measured from the centre of the transect line to the centre of the dung pile (Fig. 2). Location of transects were determined using a Garmin 76SC $\times$ global positioning system, a Suunto compass and 1: 50,000 topographic maps. Dung-piles observed while walking the transects were identified, counted and aged using the categories described in Table 1.

The observer walked along the centre-line of the transect. Whenever a dung-pile was spotted, the perpendicular distance of the dung-pile from the line transect was recorded. Some dung-piles, especially those further from the centre-line, may not have been seen at all.

Dung-piles were classified according to their shape, i.e., the probability of being seen from the centre-line of transect. Only dung-piles in categories S1-S4 are used to estimate dung-pile density.

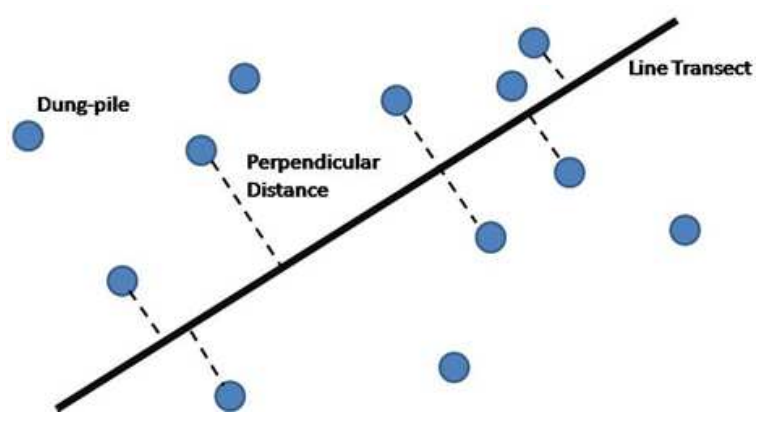

Fig. 2: Diagrammatic representation of a line transect

Table 1: Dung-pile categories based on condition of the dung

\begin{tabular}{|c|c|}
\hline Categories & Description \\
\hline$\overline{S 1}$ & Boli intact, very fresh, moist, with odor \\
\hline S2 & Boli intact, fresh but dry, no odor \\
\hline S3 & $\begin{array}{l}\text { Some of the boli have disintegrated, } \\
\text { others are still recognizable as boli }\end{array}$ \\
\hline S4 & $\begin{array}{l}\text { All boli completely disintegrated; } \\
\text { Dung pile now forms an amorphous flat mass }\end{array}$ \\
\hline S5 & $\begin{array}{l}\text { Decayed to the stage where it would be unlikely } \\
\text { to be detected at a range of } 2 \mathrm{~m} \text { from the centre line }\end{array}$ \\
\hline
\end{tabular}

Estimation of the defecation rate of elephants: Dung defecation rate of elephants depends on the elephant's diet, which in turn depends on the habitat type and the season (Dawson, 1992). Obtaining data on defecation rates of wild elephants was not possible due to the difficulty of tracking elephants for long periods of time. So for this study, the monitoring of defecation rates of captive Bornean elephants was undertaken. Monitoring activities were carried out, both night and day, over a continuous 12 hour time block, over a minimum of 10 time blocks. At least one individual from each age/sex class was included in the monitoring as recommended by Dawson and Dekker (1992). The defecation rate observations were carried out using seven domesticated elephants, located at Lok Kawi Botanical Zoo, Sabah.

Estimation of the mean rate of dung decay: The rate of dung decay depends on a combination of several factors that include the action of dung beetles, exposure to different climatic factors and the composition of the dung itself. Ideally, 50 fresh dung-piles of known dates of deposition from different habitats, representing different diets, should be monitored from the day of deposition until they completely disappear (Dawson and Dekker, 1992).

The rate of decay measurements was carried out using 90 dung piles, in Ulu Segama Malua Forest Reserve. The dung piles were located in forests of different condition, which included (i) closed-canopy (forest canopy ranged between $80-100 \%$, which normally represents undisturbed forest), (ii) semi-closed 
canopy (forest canopy ranged between $40-80 \%$, which normally represents secondary forest or logged forest) and (iii) open canopy (forest canopy ranged between 0$40 \%$, which represents treeless or heavily logged forest). The decay condition was recorded every two weeks based on categories identified in Table 1 . The dung decay observations were carried out from January 2007- November 2007.

Estimation of elephant density: A new programme, DISTANCE, which allows the selection of different models and also includes a range of different options, has been prepared by Burnham et al. (1980). Densities were analysed following line-transect analysis guidelines and were computed using the software Distance v6.0 (Meredith, 2008). In a first exploratory phase, there is a need to build up boxplots of perpendicular distances to identify outliers. These outliers were then discharged (if necessary) from the data set in setting up a proper truncation level. In a second step, the probability of next detection was estimated using seven models combining probability density function (uniform, halfnormal and hazard-rate) with adjustments (cosines, simple and hermite polynomials). The model with the lowest Akaike's Information Criterion (AIC) was selected for each sampling zone unit.

There is a need to create a data-file containing the data on perpendicular distances. The programme will read this file and use the perpendicular distances to calculate $\mathrm{f}(0)$. This is an estimate of the reciprocal of the 'Effective Strip Width' (ESW). This is defined as the perpendicular distance for which the number of dung-piles missed between the line and the ESW is equal to the number of dung-piles beyond the ESW that are detected.

The density of dung-piles, D, is then:

$$
\mathrm{D}=\operatorname{n.f}(0) / 2 \mathrm{~L}
$$

Where:

$\mathrm{n}=$ The number of droppings

$\mathrm{L}=$ The total length of the transects in which they were recorded
The methods for estimating the variance of $\mathrm{D}$ and the confidence limits are given by Burnham et al. (1980) and Meredith (2008). F (0) is the probability density function of detected distances from the line, evaluated at zero distances. The calculation is done automatically by the programme distance 6.0 .

Density (D) is estimated for each area and the population size $(\mathrm{N})$ is computed based on the size of the suitable habitat area. Often an encounter rate $n / L$ is computed as an index for sample size considerations or even as a crude relative density index.

Size of suitable habitat in each forest reserve and landuse activities: Elephants' presence and absence data were recorded in the Geographical Information System (GIS). For each record, the ecological parameters were derived from the location where the elephant occurrence signs were found. A total distance of $767.76 \mathrm{~km}$ has been surveyed in the study areas either on foot or by vehicle and the survey routes followed wildlife trails, logging roads and abandoned logging roads. The occurrence trend for the elephants is presented for each ecological parameter, namely (i) terrain elevation, (ii) slope pattern, (iii) forest type and (iv) distance of the area from the nearest permanent water sources (main river), with a pre-determined weight (WWF-Malaysia, 2008).

Table 2 shows the size of the suitable habitat available in each elephant managed range in Sabah, based on the habitat suitability study (WWF-Malaysia, 2008). During the survey period, the existing landuse activities in and adjacent to the forest areas were also recorded for reference in order to verify the status of the elephant density in the surveyed range.

\section{RESULTS}

Line transects survey: Two hundred and sixteen $(n=216)$ straight line transects covering a total distance of $186.12 \mathrm{~km}$ were walked in five main elephant managed ranges. The average length of transects in the five ranges was $862 \mathrm{~m}$.

Table 2: Size and status of key elephant habitat for each forest

\begin{tabular}{llll}
\hline No. Name of elephant range & Size of the key habitat area used by elephant $\left(\mathrm{km}^{2}\right)$ & Current land use activities \\
\hline 1 & Tabin Range (Tabin Wildlife Reserve) & 569.10 & Wildlife reserve \\
2 & Lower Kinabatangan Range & Fragmented forest reserve \\
3 & $\begin{array}{l}\text { Central forest of Sabah (Ulu Segama, } \\
\text { Danum Valley, Malua, Kuamut, Gunung }\end{array}$ & 953.15 & $\begin{array}{l}\text { Commercial forest (logging ongoing, } \\
\text { forest conversion to mono plantation, } \\
\text { silvi-culture and restoration ongoing) }\end{array}$ \\
$\begin{array}{l}\text { Rara Kalabakan and Sapulut Forest Reserves) } \\
4\end{array}$ & North Kinabatangan Range (Deramakot, \\
$\begin{array}{l}\text { Tangkulap and Segaliud Forest Reserves) } \\
\text { Ulu Kalumpang Range (Ulu Kalumpang Forest } \\
\text { Reserve) }\end{array}$ & 458.30 & $\begin{array}{l}\text { Commercial forest (logging, silvi- } \\
\text { culture and restoration ongoing) } \\
\text { Protected forest (encroachment by } \\
\text { oil palm plantation) }\end{array}$ \\
\hline
\end{tabular}

Source: WWF-Malaysia, 2008 
OnLine J. Biol. Sci., 10 (2): 92-102, 2010

Table 3: Summary of the number of transects, average, minimum and maximum surveyed distance

\begin{tabular}{|c|c|c|c|c|c|c|c|}
\hline No. & Survey site & No. of transect & Average $(\mathrm{km})$ & $\operatorname{Min}(\mathrm{km})$ & $\operatorname{Max}(\mathrm{km})$ & Total $(\mathrm{km})$ & $\mathrm{ESW}(\mathrm{m})$ \\
\hline 1 & Tabin range & 55 & 0.68 & 0.50 & 1.00 & 37.30 & 1.06 \\
\hline 2 & Lower Kinabatangan range & 16 & 0.84 & 0.40 & 1.00 & 13.49 & 0.52 \\
\hline 3 & $\begin{array}{l}\text { central forest of Sabah } \\
\text { (Ulu Segama, Danum Valley, } \\
\text { Malua, Kuamut, Gunung Rara } \\
\text { and Kalabakan) }\end{array}$ & 104 & 0.93 & 0.50 & 1.10 & 97.14 & 1.85 \\
\hline 4 & $\begin{array}{l}\text { North Kinabatangan range } \\
\text { (Deramakot, Tangkulap and } \\
\text { Segaliud forest reserve) }\end{array}$ & 34 & 0.97 & 0.4 & 1.20 & 33.05 & 1.86 \\
\hline 5 & Ulu Kalumpang range & 7 & 0.96 & 0.70 & 1.00 & 6.70 & 1.19 \\
\hline
\end{tabular}

Table 4: Elephant dung defecation rate per day

\begin{tabular}{|c|c|c|c|c|c|c|c|c|c|c|c|c|c|}
\hline Elephant & Sex* & Age (years) & Day 1 & Day 2 & Day 3 & Day 4 & Day 5 & Day 6 & Day 7 & Day 8 & Day 9 & Day 10 & Mean \\
\hline Limba & $\mathrm{F}$ & 24 & 8 & 9 & 11 & 11 & 9 & 11 & 12 & 9 & 9 & 10 & 9.9 \\
\hline Rocco & M & 22 & 9 & 9 & 11 & 9 & 8 & 11 & 10 & 10 & 10 & 11 & 9.8 \\
\hline Komali & $\mathrm{F}$ & 15 & 6 & 8 & 8 & 10 & 8 & 9 & 9 & 9 & 9 & 11 & 8.7 \\
\hline Miss & F & 21 & 7 & 8 & 10 & 10 & 8 & 8 & 10 & 10 & 10 & 12 & 9.3 \\
\hline Boy & M & 5 & 6 & 6 & 7 & 8 & 8 & 9 & 7 & 10 & 10 & 11 & 8.2 \\
\hline Tikiri & M & 7 & 6 & 6 & 5 & 8 & 7 & 9 & 6 & 8 & 8 & 11 & 7.5 \\
\hline Girl & $\mathrm{F}$ & 7 & 6 & 8 & 7 & 8 & 7 & 8 & 6 & 7 & 7 & 10 & 7.4 \\
\hline
\end{tabular}

Note: $\mathrm{M}=$ Male, $\mathrm{F}=$ Female. Overall mean dung defecation rate: 8.68; Min: 6; Max: 12; Range: 6; Standard deviation/ standard error: $1.67 / 0.199$. The mean dung defecation rate is $8.68 \pm 0.19(\mathrm{SD}=1.67)$

Table 5: Dung decay rate observed in three different quality forests

\begin{tabular}{llll}
\hline Number of dung samples & Canopy status /forest condition & Emergent trees & Dung decay rate (days) \\
\hline 30 & Closed canopy/stratum 1-2 & more than 9 & $113.067 \pm 7.350$ \\
30 & Semi canopy/stratum 3-4 & $1-8$ & $130.133 \pm 11.883$ \\
30 & Open area near logging road/stratum 5 & 0 & $156.667 \pm 12.450$ \\
\hline
\end{tabular}

A higher average transect length could not be achieved due to steepness of the terrain, or thickness of the undergrowth at sites with secondary forest, or the difficulty in crossing large rivers.

Table 3 provides a summary of the number of transects, average, minimum and maximum surveyed distance including total surveyed distance in each range.

Estimation of the defecation rate of elephants: The defecation rate was observed for 24 hours, for 10 days. The observation was taken from 6.00-6.00 am (next day). Table 4 shows the defecation rate for the elephants. The mean defecation rate was $8.68 \pm 0 / 19$ $(\mathrm{SD}=1.67)$. The defecation rate for the elephant calves (less than 8 years old) was less than the adult's rate.

Estimation of mean rate of dung decay: Based on 90 dung piles, gathered and placed in 3 different areas (closed-canopy, semi open canopy and open-canopy), the mean dung decay rate was estimated as at $133.29 \pm 6.284$ days.

The decay rate for the elephant dung in the closed canopy forest is faster than in open canopy forest areas (Table 5). This is likely to be due to a greater number and type of decomposition agents present in the better quality forest (closed canopy) compared to degraded forest (open-canopy).
Estimation of the elephant density in five main elephant ranges: A new programme, distance 6.0 was used, which allows the selection of different models (key function) and also a range of different options of adjustment terms. Data was prepared as a data-file containing the data on perpendicular distances. The programme uses this file and use the perpendicular distances to calculate $\mathrm{f}(0)$ and estimate the reciprocal of the Effective Strip Width (ESW).

Table 6 shows the summary of 'Key Function' and 'Adjustment Terms' used to generate the lowest AIC's value, using the software distance 6 .

By using the distance 6.0 software, various combinations of the key and adjustment function provide flexibility in modeling the detection function $\mathrm{g}$ (x). If the distance data are distributed in a more spiked form, the choice of model (Key function and Adjustments term) is more difficult and estimation of density more tenuous. The models recommended in this computation are likely to perform reasonably well, since the value for AIC that is generated by each model is used as a selection guideline, where elephant density estimated by using a model that could generate the lowest value of AIC will be considered as a reasonable density. 
Table 7 provides a summary of the estimated elephant density for the ranges and Table 8 for the reserves areas within these ranges. This is based on the value of the lowest Akaike's Information Criterion as a selection guideline. A combination of key function and adjustment terms was assessed and identified, in order to provide more accurate analyses.

The central forest has the highest estimated number of elephants, followed by Tabin Wildlife Reserve, with a population of 1,132 (95\% CI: 748-1,713) and 342 (95\% CI: 152-774) respectively. The third highest population is in Lower Kinabatangan Range followed by North Kinabatangan and Ulu Kalumpang, with a population 298 (95\% CI: 152-581), 258 (95\% CI: 131$511)$ and 10 (95\% CI: 1-73) respectively.

However, in terms of elephant density, Lower Kinabatangan range has the highest density of elephants, 2.15 individuals per $\mathrm{km}^{2}$.

Elephant abundance in each forest reserve: Upper catchment of Ulu Segama Forest Reserve (Fitch) has the highest density of elephants 3.69 elephants per $\mathrm{km}^{2}$, followed by the Danum Valley Conservation Area, 2.35 elephants per $\mathrm{km}^{2}$ and Lower Kinabatangan Wildlife Reserve, 2.15 elephants per $\mathrm{km}^{2}$. Tangkulap Wildlife Reserve 1.26 elephants per $\mathrm{km}^{2}$ and Deramakot Forest Reserve which is adjacent to Tangkulap Forest Reserve 0.86 elephants per $\mathrm{km}^{2}$.

Malua Forest Reserve which is contiguous with Kuamut Forest Reserve and Malubuk Virgin Jungle Reserve has a density of 1.41 elephants per $\mathrm{km}^{2}$.

Ulu Kalumpang Forest Reserve and KalabakanSapulut-Maliau Forest Range have the lowest density of elephants, 0.12 and 0.28 elephants per $\mathrm{km}^{2}$ respectively. The elephant density results for all reserves are shown in Table 8 and Fig. 3.

Although during transect surveys in the northern part of Ulu Segama Forest Reserve and TelupidTongod Forest Reserve, no elephant dung was found, it is known from sightings that 2-3 elephants are present in the area. Elephant tracks were also observed along transects, elephant trails and logging roads in the areas.

Table 6: Summary of models used in density estimation computation

\begin{tabular}{llll}
\hline No. & Location of survey & Key function & Adjustment terms \\
\hline 1 & Tabin range & Half-normal & Cosine \\
2 & Lower Kinabatangan range & Uniform & Cosine \\
3 & Central forest of Sabah (Ulu Segama, Danum valley, Malua, Kuamut, & Half-normal & Simple-polynomial \\
& Gunung Rara and Kalabakan) & & \\
4 & North Kinabatangan range (Deramakot, Tangkulap and Segaliud forest reserve) & Uniform & Simple-polynomial \\
5 & Ulu Kalumpang range & Uniform & Cosine \\
\hline
\end{tabular}

Table 7: Estimated elephant density and population in each survey range

\begin{tabular}{|c|c|c|c|c|c|c|c|c|}
\hline \multirow[b]{2}{*}{ No. } & \multirow[b]{2}{*}{ Survey site } & \multicolumn{3}{|c|}{$\mathrm{D}$ (density) parameter } & \multicolumn{4}{|c|}{$\mathrm{N}$ (number) parameter } \\
\hline & & $\begin{array}{l}\text { Point estimate } \\
\text { (ind. } \mathrm{Km}^{-2} \text { ) }\end{array}$ & $\begin{array}{l}\text { Standard } \\
\text { error }\end{array}$ & $\begin{array}{l}\text { Percent coef. } \\
\text { of variation }\end{array}$ & $\begin{array}{l}\text { Point estimate } \\
\text { (No of ind.) }\end{array}$ & $\begin{array}{l}\text { Standard } \\
\text { error }\end{array}$ & $95 \% \mathrm{C}$ & \\
\hline$\overline{1}$ & Tabin range & 0.60 & 0.28 & 46.24 & 342 & 158.13 & 152 & 774 \\
\hline 2 & Lower Kinabatangan range & 2.15 & 0.84 & 38.87 & 298 & 115.84 & 152 & 581 \\
\hline 3 & $\begin{array}{l}\text { Central forest of Sabah (Ulu Segama, Danum } \\
\text { Valley, Malua, Kuamut, Gunung Rara and } \\
\text { Kalabakan) }\end{array}$ & 1.18 & 0.34 & 28.52 & 1,132 & 322.85 & 748 & 1,713 \\
\hline 4 & $\begin{array}{l}\text { North Kinabatangan range (Deramakot, } \\
\text { Tangkulap and Segaliud forest reserve) }\end{array}$ & 0.56 & 0.22 & 39.46 & 258 & 101.81 & 131 & 511 \\
\hline 5 & Ulu Kalumpang range & 0.12 & 0.11 & 99.46 & 10 & 9.95 & 1 & 73 \\
\hline
\end{tabular}

Table 8: The summary of the estimated elephant density in each forest reserve

\begin{tabular}{|c|c|c|c|c|}
\hline \multirow[b]{2}{*}{ No. } & \multirow[b]{2}{*}{ Survey site } & \multicolumn{3}{|l|}{$\mathrm{D}$ (density) parameter } \\
\hline & & Point estimate (ind. per $\mathrm{km}^{2}$ ) & Standard error & Percent coef. of variation \\
\hline 1 & Tabin wildlife reserve & 0.60 & 0.28 & 46.240 \\
\hline 2 & Lower Kinabatangan wildlife reserve & 2.15 & 0.84 & 38.870 \\
\hline 3 & Ulu Segama forest reserve (lower catchment) & 0.93 & 0.34 & 36.640 \\
\hline 4 & Malua forest reserve & 1.41 & 0.62 & 43.890 \\
\hline 5 & Kalabakan forest reserve and Sapulut forest reserve & 0.28 & 0.14 & 48.920 \\
\hline 6 & Danum valley conservation area & 2.35 & 1.30 & 55.670 \\
\hline 7 & Deramakot forest reserve & 0.86 & 0.12 & 135.96 \\
\hline 8 & Gunung Rara and Kuamut forest reserve & 1.18 & 0.69 & 58.650 \\
\hline 9 & Tangkulap forest reserve & 1.26 & 0.64 & 50.620 \\
\hline 10 & Segaliud Lokan forest reserve & 1.41 & 0.62 & 44.390 \\
\hline 11 & Ulu Kalumpang forest reserve & 0.12 & 0.11 & 99.460 \\
\hline 12 & Ulu Segama forest reserve (upper catchment) & 3.69 & 1.84 & 49.980 \\
\hline
\end{tabular}


OnLine J. Biol. Sci., 10 (2): 92-102, 2010

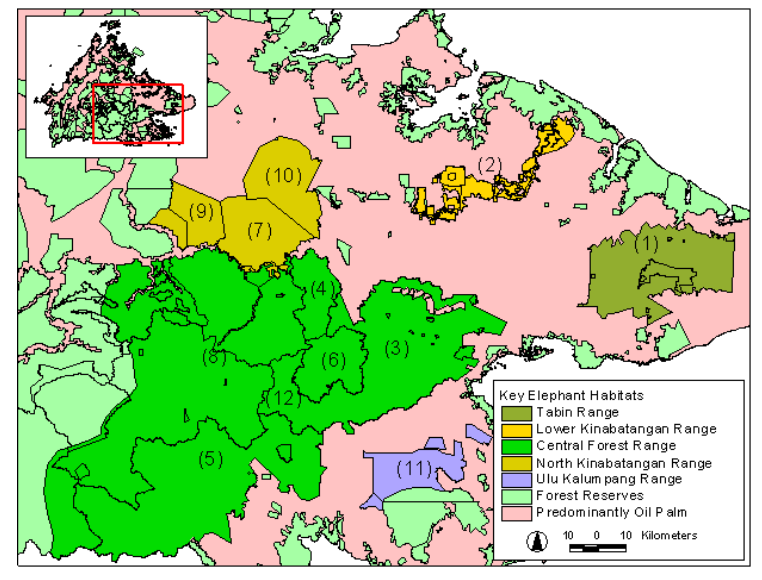

Fig. 3: Location of the specific forest sites where field survey was carried out (Table 8)

\section{DISCUSSION}

Estimation of mean rate of dung decay: The rates of dung decomposition were variable due to several factors; (i) type of vegetation consumed by the elephant (diet of elephants), (ii) type of forest cover and (iii) weather condition during the study period. The data indicates that the mean rate of the dung decay is significantly different in different quality forests (refer to Table 5). In closed forest (undisturbed) forest the mean rate of dung decay is faster (113.1 days) than in more open forest (degraded) (156.7 days, Rates of dung decomposition recorded previously in tropical rainforests of Southeast Asia (140.8-153.8 days) are similar to the rate recorded in disturbed forest in this study, It is unknown whether these rates were derived from studies conducted in different quality forests (Boonratana, 1997; Dawson, 1992).

In this study dung decay rates were undertaken in three different forest categories (poor, moderate and good). As most of the survey area is covered with a combination of the three forest categories, the mean dung decay rate calculated should not vary because of different forest categories.

Other factors in this study that could have affected the estimation of the dung decay rate are different climatic conditions and the type of animals present in each forest area.

Wanghongsa and Boonkird (2004) found that weather conditions had a significant effect on dung decay rates; they decayed 2.14 times faster in the wet season. This is probably due to the high activity of insects in the wet season. About 29 families of insects were retrieved from 100 dung piles (Wanghongsa and Boonkird, 2004). It is extremely unlikely that dung-pile
Table 9: Mean rainfall and mean temperature from 2006-2008

\begin{tabular}{llll}
\hline Year & Wet days & Mean rainfall $(\mathrm{mm})$ & Mean temperature $\left({ }^{\circ} \mathrm{C}\right)$ \\
\hline 2006 & 183 & 2,618 & 26.5 \\
2007 & 185 & 2,310 & 26.7 \\
2008 & 185 & 2,185 & 26.6 \\
\hline
\end{tabular}

Source: Malaysian Meteorological Department, 2006

decay rates would remain constant for a period that includes both drought and non-drought periods given that rainfall is widely recognized as a major factor affecting decay rates (White, 1995; Barnes et al., 1997; Nchanji and Plumptre, 2001).

The average annual rainfall across the study sites varies from 2,185.4-2,618.3 mm, with temperature between $26.5-26.7^{\circ} \mathrm{C}$ (Table 9). The constant climatic conditions throughout the year and throughout the study area are unlikely to have a great seasonal effect on dung decay rate since there is no defined wet season that would increase the activity of the insects (Wanghongsa and Boonkird, 2004). Therefore the effect of the weather on the decay rate is considered to have a minimal effect in this study.

The presence of ground feeding birds such as jungle fowl, partridges, quails etc can accelerate the deterioration rate of elephant dung piles. They usually ransack dung for insects they prey upon (Wanghongsa and Boonkird, 2004).

The mean dung decay rate calculated is considered suitable for the analysis.

Defecation rate of elephants' dung: The dung survey assumed that all elephants defecate at the same rate. In fact, the rate of defecation remains inconclusive. The mean dung defecation rate was calculated as $8.68 \pm 0.19$ per day. The dung defecation rate used in earlier density and population surveys in Tabin Wildlife Reserve by Dawson (1992) was higher (13.2033 \pm 0.789 dung piles per day). The defecation rate study was carried out in the rainforests of Southern India. This defecation rate was reportedly similar to the rate obtained for captive elephants in Thailand that were fed with natural fodder (Dawson, 1992).

The defecation rate for the elephants may depend on:

- The age and sex of elephants, including the elephant's body size

- The spatial and temporal variations of weather within the elephants' habitat

- The amount of food that is given or provided to the domesticated elephant per day

In studying the defecation rate of domesticated elephants, Wanghongsa and Boonkird (2004) discovered significant difference in defecation 
rate between age and sex of elephants. These differences can be attributed to physiology of elephants, which is different based on age and sex (Gakuya et al., 2003).

In addition, spatial and temporal variations have been found in elephant's defecation rate. In Africa, elephants defecated more in the rainy season than in the dry season (Ruggiero, 1992), a factor of 1.5 (Jachmann and Bell, 1984). Sivaganesan and Kumar (1994) investigated defecation rates in humid zones of Asia and found that the rates were $>184 \%$ higher than defecation rates in a dry zone examined by (Wanghongsa and Boonkird, 2004).

The defecation rate calculated in this study was based on seven domestic elephants that were kept in a closed zoo. These elephants were chained and allowed to feed on natural fodder only in the daytime $(12-13 \mathrm{~h}$ ) within the radius of their confinement. At night they were chained. This output cannot be compared with wild elephants that feed 17-19 h a day (Vancuylenberg, 1977).

We believe that use of a much lower defecation rate calculated from captive animals, may lead us to overestimate elephant density in the study area. Our calculated dung defecation rate was much lower compared to the one that was gathered from a study of free-ranging elephants in Way Kambas National Park, Sumatera, Indonesia (Tyson et al., 2002).

Status of elephant's dung along the survey transect: In order to determine the status of the elephant's dung distribution in the survey area, the numbers of dung-piles were calculated with increasing distance from the rivers and roads. 16 out of a total of 216 transect lines were placed perpendicular to the Kinabatangan River and its major tributaries. From a total of 81 dung-piles encountered along these 16 transects, $67.9 \%$ of the dung piles were within the first $500 \mathrm{~m}$ and $32.10 \%$ of the total dung-piles were recorded more than $500 \mathrm{~m}$ away from the riverside. Figure 4 shows the percentage and distance of dung piles from the main river.

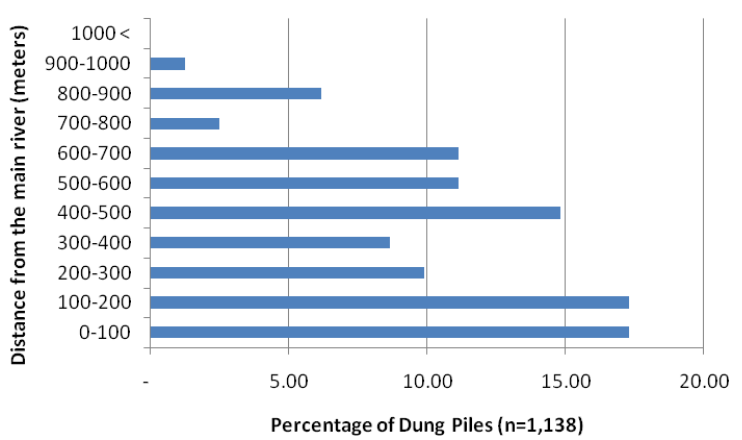

Fig. 4: Percentage and distance of dung piles from the main river
A total of 1,057 dung-piles were encountered along the remaining 200 transects that were placed perpendicular to logging roads. $64.7 \%$ of the total dungpiles were encountered within the first $500 \mathrm{~m}$ of the transect, $35.3 \%$ of the dung-piles were encountered more than $500 \mathrm{~m}$ from the road (Fig. 5).

The observations indicate that, the density estimates for elephants are likely to be over-estimated. The elephant's dung observations were recorded near where there is the greatest density of elephants, i.e. nearby major roads and rivers. Thus, densities for the whole reserve could be a gross over-estimate. This means that there are likely to be far less elephants than the data indicated.

However, this argument is only true if the density of roads in the forest is low. Most of the survey area in this study was logged 30 years ago (except Danum Valley Range) and hence most of the survey area has a high density of roads, including abandoned logging roads. The distance between one logging road and another is between 1-3 km. Therefore we consider that the estimated elephant population is not likely to be an overestimation.

Elephant abundance in each forest reserve and the effect of forest conversion, forest fragmentation and habitat limits: Malua Forest Reserve which is contiguous to Kuamut Forest Reserve and Malubuk Virgin Jungle Reserve has a density of 1.41 elephants per $\mathrm{km}^{2}$. In 1997, the elephant density in Malua Forest Reserve was calculated at 0.79 elephants per $\mathrm{km}^{2}$ (Boonratana, 1997). The increase of the density of elephants in Malua may be due to logging activities in the adjacent forest reserves (namely Kuamut Forest Reserve and within Malua Forest Reserve itself). This argument is supported by the evidence that elephant groups moved outside Malua range into the oil palm plantations during the survey period.

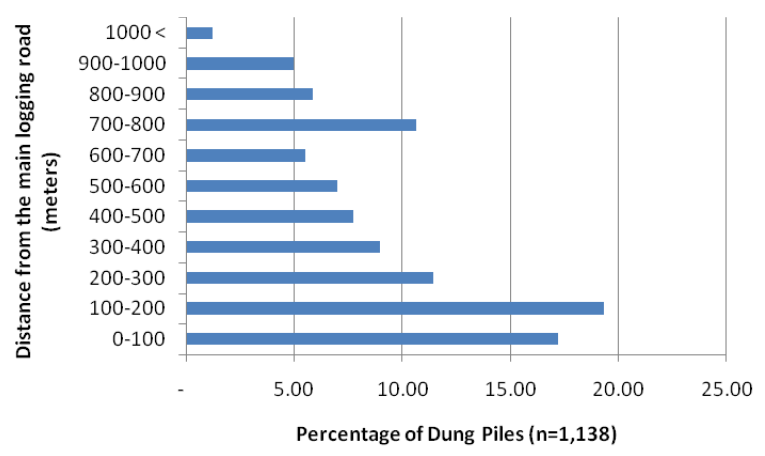

Fig. 5: Percentage and distance of dung piles from the main logging road 


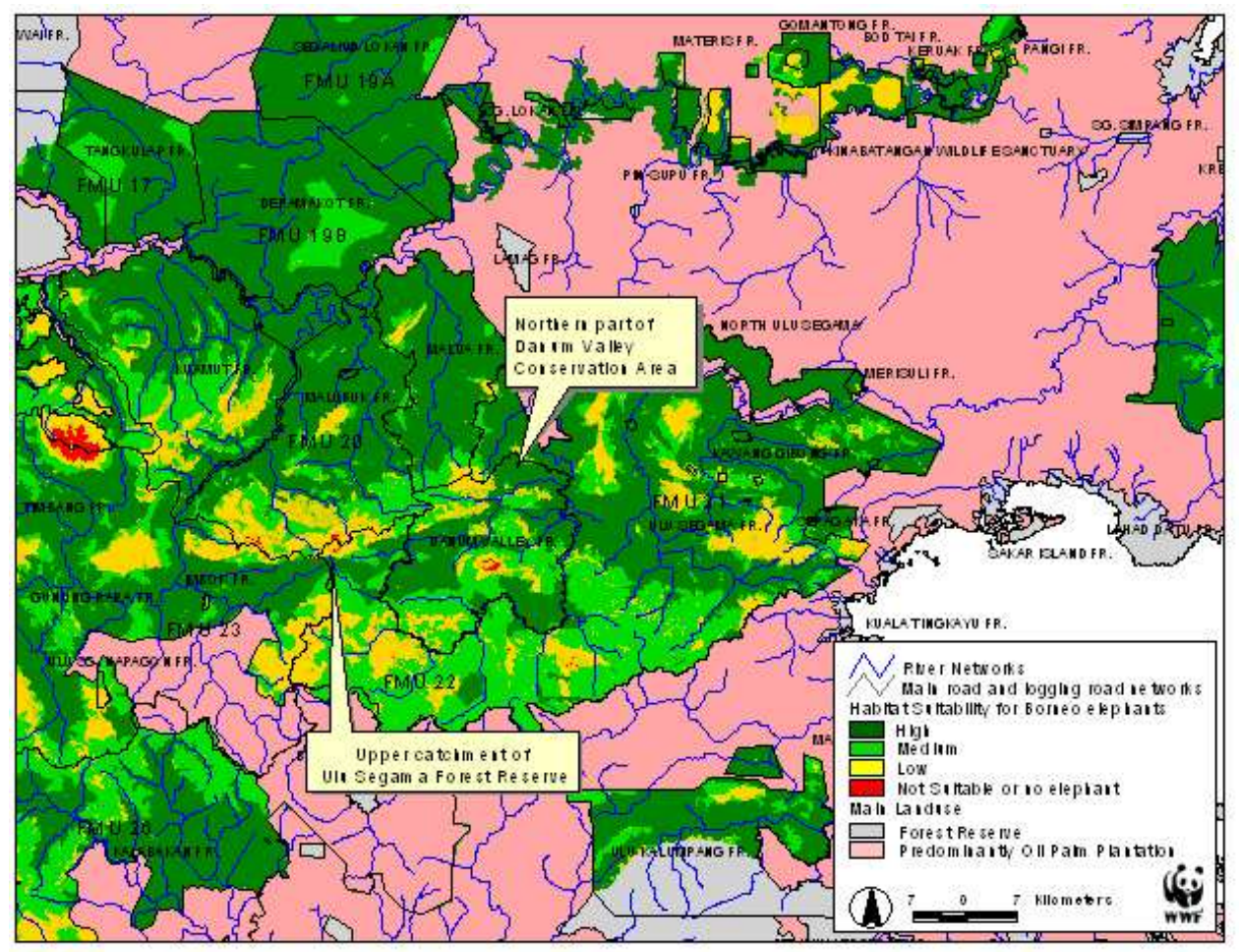

Fig. 6: Location of suitable habitat for elephants in the northern part of DVCA and upper catchment of Ulu Segama Forest Reserve

Ulu Kalumpang Forest Reserve and Kalabakan-Sapulut-Maliau Range have the lowest density of elephants, at 0.12 and 0.28 elephant per $\mathrm{km}^{2}$ respectively. Boonratana (1997) estimated at least 0.01 elephant per $\mathrm{km}^{2}$ in Kalabakan Forest Reserve. This indicates that the elephant density has increased with loss of key habitat due to conversion to large-scale plantation. Elephants are now absent from the main Kalabakan Forest Reserve, especially in the Benta Wawasan oil palm area as from 2005 key habitat has been destroyed.

As habitat has been converted to agriculture (oil palm and industrial tree plantations), it appears that there has been an increase in elephant density, in the remaining habitat in the northern part of Danum Valley Conservation Area (DVCA) and upper catchment of Ulu Segama Forest Reserve (known locally as Fitch area, south-west part of Danum Valley), as elephant density is high, being 3.69 and 2.35 elephants per $\mathrm{km}^{2}$ respectively.

Figure 6 shows that the extent of suitable habitat for elephants remaining in these two areas, identified by the habitat suitability work. The elephant population density is high as the elephants are concentrated in a small area.
Estimate of Sabah's elephant population: This study estimates the number of elephants remaining in the five main elephant managed ranges in Sabah to be about $2,040 \quad(95 \%$ CI 1,184-3,652). We believe the differences between these population estimates and those of Dawson (1992); Andau et al. (1992) and Ambu et al. (2002) reflect the differences in survey methods used. Ambu et al. (2002) relied primarily on interviews with forest managers and also on secondary data derived from brief field trips to come up with estimates. Dawson (1992) and Andau et al. (1992) derived their estimate by extrapolating from their survey work in Lower Kinabatangan, Tabin Wildlife Reserve and Deramakot Forest Reserve. Therefore, we believe that the methods used to estimate the population size in 1992 and 2002 may have led to an underestimate of the elephant population size in Sabah.

Viable Habitat for elephants: Given the abundance of the elephants in each forest range, the issue of habitat viability for the elephants needs to be addressed. There are three major habitat attributes, namely size, integrity and quality that have to be considered for the conservation of the elephant population. According to Sukumar (2003), the minimum viable habitat area is 
related to the minimum viable population and the capacity of the habitat (the density of elephants under so-called equilibrium conditions). Sukumar (2003) suggested that the viability of the habitat is still good if an equilibrium density of the elephant ranges between 0.5-1.5 elephants per $\mathrm{km}^{2}$. Based on this, Lower Kinabatangan range may not be viable habitat at present for the elephants since the density of elephants in this area is 2.15 elephants per $\mathrm{km}^{2}$. Linking habitat with forest corridors will improve the habitat viability. The other forest habitat ranges (i) Tabin range, (ii) North Kinabatangan range, (iii) Central forest range and (iv) Ulu Kalumpang range would be considered viable.

Viable elephant populations: According to Sukumar (2003), a population of 1,000-3,000 elephants or more, are a viable population to be targeted for long-term conservation. However, for Asian elephants, one does not have the luxury of many large populations. In our study, four of the five main populations are fewer than 1,000 elephants. Only the central forest area supports an elephant population of more than 1,000 individuals. For elephant conservation in Sabah it is necessary to protect all five key populations and to address where possible limitations to the growth of these populations particularly where habitat is the limiting factor.

\section{CONCLUSION}

The status of the elephant population in the study area was carried out and determined using the dung count line transects survey, supported by long term monitoring of dung decay rates. Many factors may contribute to an over-estimation or under-estimation of ecological density and population, namely (i) the use of unsuitable defecation rate of an elephant; (ii) the use of unsuitable dung decay rate; (iii) the size of the actual key habitat or suitable habitat for the elephants. Although in this study a number of factors may have contributed to an over or under-estimate of density, it is believed that the population figures are reasonably accurate and can used as a good indicator of population change over time, if the method is repeated.

Our survey showed that the minimum number of elephants remaining in the five main elephant managed ranges in Sabah is about 2,040 (95\% CI 1,184-3,652). These results provide new baseline data for the Bornean elephant population.

The elephant density and population size varies throughout the five key ranges affected by (i) conversion of lowland forest; (ii) fragmentation of habitat and (iii) existing land use activities such as logging.
We found that the central forest contains the highest number of elephants (more than 1,000), which indicates the importance and viability of this population to be conserved. This highlights the importance of protecting the central forest which is intact and contiguous with other forest to ensure the future survival of the Bornean elephant.

The challenge now is to ensure that no further loss and habitat fragmentation occurs in these five key habitat ranges. Illegal killing of elephants as a result of human-elephant conflict is also an ongoing threat for the remaining small and fragmented populations. This needs to be addressed through enhanced mitigation efforts.

\section{ACKNOWLEDGEMENT}

We thank WWF-US (Mr. Barney Long), USFWS (Dr. Meenakshi Nagendran), WWF-Netherland (Mr. Hans Beukeboom) and WWF-Germany (Mr. Stefan Ziegler) for their financial support to enable us to execute the first state-wide elephant survey in Sabah. We also would like to thank the Director of Sabah Forestry Department (Datuk Sam Mannan) and Director of Sabah Wildlife Department (Dr. Laurentius Ambu), for granting us permission and field research support in forest reserves and the wildlife sanctuary. Also thanks goes to all Sabah Wildlife Department staff (Dr. Roza Sipangkui and Mr. Elis Tambing) and Borneo Species Programme staff (Mr. Jabanus Miun, Mr. Engelbert Dausip, Mr. William Joseph, Mr. Edwin Matulin, Mr. Middle Seen Kapis, Mr. John Japil and Mr. David James) for their support in executing the first elephant census work in Sabah using a systematic approach.

\section{REFERENCES}

Ambu, L.N., P.M. Andau, S. Nathan, A. Tuuga and S.M. Jensen et al., 2002. Asian Elephant Action Plan. Sabah, Malaysia. http://www.sabah.gov.my/jhl/Last\%20ed\%20of\%2 0Elephant\%20strategy.pdf

Andau, M., S. Dawson and J. Sale, 1992. A review of elephant numbers in Sabah. http://www.asesg.org/PDFfiles/Gajah\%2018/3\%20 A\%20Review\%20of\%20Elephant $\% 20$ Numbers $\% 2$ 0in\%20Sabah.pdf

Barnes, R.F.W. and K.L. Jensen, 1987. Distribution of elephants in Gabon. Afr. J. Ecol., 29: 54-63.

Barnes, R.F.W., B. Asamoah-Boateng, J. Naada Majam and J. Agyei-Ohemeng, 1997. Rainfall and the population dynamics of elephant dung-piles in the forests of southern Ghana. Afr. J. Ecol., 35: 39-52. 
Boonratana, R., 1997. A state-wide survey to estimate the distribution and density of the Sumatran rhinoceros, Asian elephant and banteng in Sabah, Malaysia. Wildlife Conservation Society Project Report, pp $1-76$. http://www.rhinoresourcecenter.com/index.php?s= $1 \&$ act=refs\&CODE=ref_detail\&id=1165242387

Burnham, K.P., D.R. Anderson and J.L. Laake, 1980. Estimation of density from line transect sampling of biological populations. Wildlife Monogr., 72: 1-202.

Buckland, S.T., D.R. Anderson, K.P. Burnham, J.L. Laake and D.L. Borchers et al., 2001. Introduction to Distance Sampling, Estimating Abundance of Biological Populations. Oxford University Press, Oxford, ISBN: 0-19-850927-8, pp: 67-99.

Cranbrook, E., J. Payne and M.U. Charles, 2008. Origin of the Elephants Elephas maximus L. of Borneo. Sarawak Museum J., 1: 1-25.

Dawson, S., 1992. Estimating elephant numbers in Tabin Wildlife Reserve, Sabah. Consultancy Report, WWF-Malaysia Project MYS 224/92, Sabah, Malaysia. http://repository.wwf.org.my/technical_reports/E/E stimatingElephantNumbersInTabinWildlifeReserve Sabah.pdf

Dawson, S. and A.J.F.M. Dekker, 1992. Counting Asian Elephants in Forests. FAO, Bangkok, pp: 56.

Fernando, P., T.N. Vidya, J. Payne, M. Stuewe and G. Davison et al., 2003. DNA analysis indicates that Asian elephants are native to Borneo and are therefore a high priority for conservation. Public Library of Science, San Francisco, California, USA., Vol. 3, pp: 382-388.

Gakuya, F., E. Wambwa, D. Ndeereh and T. Manyibe, 2003. Physiological and haematological findings in immobilized free-ranging African elephants. Pachyderm, 35: 77-81.

Jachmann, H. and R.H.V. Bell, 1984. The use of elephant droppings in assessing numbers, occupance and age structure: A refinement of the method. Afr. J. Ecol., 22: 127-141.

Malaysian Meteorological Department, 2006. Annual rainfall and mean temperature report (2006-2008); http://www.met.gov.my
Meredith, M.E., 2008. Estimating population size with line transects and DISTANCE. Problem-Solving in Conservation Biology and Wildlife Management. Blackwell Publishing, Chapter 12, ISBN: 978-14051-5287-7, pp: 88-104.

Nchanji, A.C. and A.J. Plumptre, 2001. Seasonality in elephant dung decay and implications for censusing and population monitoring in southwestern Cameroon. Afr. J. Ecol., 39: 24-32.

Ruggiero, R.G., 1992. Seasonal forage utilization by elephants in central Africa. Afr. J. Ecol., 30: 137-148.

Sivaganesan, N. and A. Kumar, 1994. Status of Feral Elephants in the Andaman Islands, India. http://www.the-easternforest.org/pages/books/Defecation.pdf

Sukumar, R., 1989. The Asian elephant: Ecology and Management. Cambridge of University Press. ISBN: 0521360803, pp: 63-69.

Sukumar, R., 2003. The Living Elephants. Oxford University Press, Oxford, ISBN: 0-19-510778-0, pp: 353-363.

Tyson, M.J., S. Hedges and A.F. Sitompul, 2002. Elephant Defecation Rate Study, Way Kambas National Park 2000/2001. Final Report to WWF, WCS and PHKA, Wildlife Conservation SocietyIndonesia Program, Bogor, Indonesia.

Vancuylenberg, B.W.B., 1977. Feeding behavior of the Asiatic elephant in south-east Sri Lanka in relation to conservation. Biol. Conserv., 12: 33-53.

Wanghongsa, S. and K. Boonkird, 2004. Estimating elephant populations in dry evergreen forest of Thailand. http://www.the-easternforest.org/pages/2547/Estimating.pdf

White, L.J.T., 1995. Factors affecting the duration of elephant dungpiles in rain forest in the Lope' Reserve, Gabon. Afr. J. Ecol., 33: 142-150.

WWF-Malaysia, 2008. Assessment of the key habitat for Borneo elephant in Sabah. WWF Technical Progress Report.

http://repository.wwf.org.my/technical_reports/A/ AssessmentOfTheKeyHabitatForBorneoElephantIn Sabah.pdf 